\title{
Gleb Vassilievich Wataghin: Physics, University and Politics in Brazil (1934-1949)
}

\author{
Luciana Vieira Souza da Silva, Bruno Bontempi Jr. \\ University of São Paulo; 308, Avenida da Universidade, Sao Paulo, Brazil; \\ vssluciana@gmail.com, bontempi@usp.br
}

\begin{abstract}
In 1934, the Russian-Italian physicist Gleb Vassil'evich Wataghin arrived in Brazil as part of an Italian diplomatic mission to organize the instruction of physics at the new Universidade de São Paulo. Still in the country, he returned to his Russian origins after Brazil's declaration of war against Italy and the other Axis countries in 1942. This article discusses how Wataghin asserted his Russian nationality to help him stay there and adapt his work. It analyzes Wataghin's path according to the methodological concept of intellectual scientists to investigate his political engagement with the organization of the scientific field, considering his work as a professor and a physicist, and his national origins. By examining the relevant sources to reconstruct his itinerary, social networks and generation, the authors consider the scientist's intellectual outlook. They conclude, among other, that Wataghin's involvement in São Paulo's Russian community, specifically the Russian Red Cross, made him the target of investigation and repression by the State Department of Political and Social Order of São Paulo. After World War II, being a physicist further aggravated suspicions of the authorities. This affected Wataghin's work environment and social network, which were also under investigation.

Keywords: Gleb Vassil'evich Wataghin, Brazilian physics, Russian Red Cross, Universidade de São Paulo

Acknowledgements and Funding: The authors acknowledge the financial support from the São Paulo Research Foundation (FAPESP), grants 2015/20490-8 and 2017/23799-5.

For citation: Vieira Souza da Silva, L., and Bontempi Jr., Bruno. "Gleb Vassilievich Wataghin: Physics, University and Politics in Brazil (1934-1949)." RUDN Journal of Russian History 19, no. 4 (November 2020): 965-978. https://doi.org/10.22363/2312-8674-2020-19-4-965-978
\end{abstract}

\section{Глеб Васильевич Ватагин: физика, университет и политика в Бразилии (1934-1949)}

\section{Лучиана Виейра Соуза да Силва, Бруно Бонтемпи мл.}

Университет Сан-Паулу; Бразилия, Сан-Паулу, Авенида да Универсидаде, 308; vssluciana@gmail.com,bontempi@usp.br

Аннотация: В данной статье рассматривается жизненный путь российско-итальянского физика Глеба Васильевича Ватагина, эмигрировавшего в Италию из России в годы Гражданской войны. В 1934 г. он прибыл в Бразилию с итальянской дипломатической миссией для организации физического факультета в новом Университете Сан-Паулу, где был вынужден остаться в связи с началом Второй мировой войны. Авторы реконструируют его жизненный путь, общественные связи, анализируют мировоззрение ученого. Они приходят к выводу, что участие Г.В. Ватагина в жизни русской общины Сан-Паулу, в частности в организации помощи СССР в годы войны через российский Красный Крест, сделало его объектом преследований со стороны Департамента политического и социального порядка города. После войны его статус ученого-физика, связанного с Россией, еще больше усилил подозрения властей к нему, что повлияло на характер деятельности и научно-гуманитарные связи Ватагина. Как установили авторы на основе нового комплекса документов, обвинения ученого в причастности к политической деятельности были

(C) Vieira Souza da Silva L., Bontempi B., Jr., 2020

c) (i) This work is licensed under a Creative Commons Attribution 4.0 International License https://creativecommons.org/licenses/by/4.0/ 
необоснованными и в основном базировались на страхе властей перед предполагаемым коммунистическим заговором в Бразилии. Как вице-президент организации, считавшейся просоветской, а значит - коммунистической, Ватагин автоматически попадал под подозрение. Для ученого же главной была его научная деятельность, связанная с изучением космических лучей и организацией научной школы на базе Университета Сан-Паулу. В этой связи как ученый и профессор университета Г.В. Ватагин уделял большое внимание международным научным связям, обмену научными кадрами. При этом ученый никогда публично не говорил о своих политических убеждениях, хотя и считал себя социалистом.

Ключевые слова: Глеб Васильевич Ватагин, бразильские физики, российский Красный Крест, Унивеситет Сан-Паоло

Благодарности и финансирование: Авторы выражают признательность за финансовую поддержку Исследовательскому фонду Сан-Паулу (FAPESP), грант 2015 / 20490-8.

Для цитирования: Виейра Соуза да Силва Л., Бонтемпи Бруно мл. Глеб Васильевич Ватагин: физика, университет и политика в Бразилии (1934-1949) // Вестник Российского университета дружбы народов. Серия: История России. 2020. Т. 19. № 4. С. 965-978. https://doi.org/ 10.22363/2312-8674-2020-19-4-965-978

\section{Gleb Wataghin and the founding of the Universidade de São Paulo}

Gleb Wataghin learned about the existence of Universidade de São Paulo (USP) just a few months after it was founded in January 1934. He may have first heard its name spoken during an enthusiastic speech of the engineer, professor and politician Theodoro Ramos, the director of USP's Faculty of Philosophy, Sciences and Letters (FFCL), to a group of diplomats in Italy. Until then, the faculty to which Ramos would be appointed existed only in the imagination of the university's founders. It would be up to him and his collaborators to set it up, including providing a building, designing the curriculum and recruiting professors. The latter led Theodoro Ramos to meet with Gleb Wataghin, putting the Russian-Italian physicist on his Brazilian path.

The university's founders were convinced that the institution they proposed was unique. During the second half of the 1920s, Brazilian academe was in considerable ferment as many condemned what they saw as serious failures in their country's system of higher education due to its imperial heritage. They criticized the lack of the "mental discipline" necessary for scientific work, which was the result of the "baccalaureate," which, designed to provide a liberal education to professionals destined for the political elite, taught amateur and false rhetoric. ${ }^{1}$ They agreed with the image foreign intellectuals, especially the French, established at conferences, meetings of the urban intellectual elite, and in the press, that the country was not capable of producing professors who could teach the sciences at the FFCL. ${ }^{2}$

This consensus about these native deficiencies led the state government of São Paulo to entrust Theodoro Ramos with a trip to various European countries to examine their system of higher education. Ramos was also tasked with hiring some scientists and professors as lecturers to help create new courses for the FFCL. ${ }^{3}$ Ultimately, São Paulo's elite hoped that, through a modern university, these academics would sow the seeds of European culture in Brazil. Coming from manifestly republican and anti-oligarchic political, cultural and business backgrounds, such as the Nationalist League, the Democratic Party, the law school, and the newspaper O Estado de S. Paulo, its members understood that the university would create the country's future leaders. This new elite was to come

\footnotetext{
${ }^{1}$ Bruno Bontempi Jr., "Nacionalismo e regionalismo em dois inquéritos sobre o ensino superior brasileiro nos anos 1920," Educar em Revista 33, no. 65 (2017): 35-50.

2 Sylvia Gemignani Garcia. Destino impar. Sobre a formação de Florestan Fernandes (São Paulo: Editora 34, 2002); Carlos Guilherme Mota, "Ecos da historiografia francesa no Brasil: apontamentos e desapontamentos," in Do positivismo à desconstrução. Idéias francesas na América (São Paulo: Edusp, 2004), 137-158.

${ }^{3}$ Carlota Boto, "A intelectualidade paulista, o Manifesto dos Pioneiros e a Universidade de São Paulo em sua primeira “missão" (1932-1934)," in História da Educação: global, nacional e regional (Vitória: Edufes, 2019).
} 
from different social backgrounds, not just the upper class, and, in a truly representative democracy, have their merits recognized by popular suffrage. ${ }^{4}$

Between February and May 1934, Theodoro Ramos met with scientists and professors, academic administrators, diplomats, and political leaders in Italy, Switzerland, Belgium, France, Germany, and Portugal, asserting, during the negotiations, his interpersonal social network, the political weight of being a representative of São Paulo government, and the Brazilian diplomatic relations. These initial encounters led to the recruitment of 19 professors, of whom 10 were French, four Italian, three German, and one each from England and Portugal. ${ }^{5}$ According to several studies of such "foreign missions" by USP, Theodoro Ramos' agreements had important political effects, such as reaffirming the former cultural bonds with France, ${ }^{6}$ enabling Mussolini's fascist regime to disseminate its propaganda to São Paulo's large Italian population, ${ }^{7}$ and permitting German Jews to pursue their careers in a setting free of growing Nazi antisemitism. ${ }^{8}$

By the same token, after arriving in Brazil, such foreign academics often found themselves involved in delicate and embarrassing situations due to the political injunctions that acted on a still incipient and heteronomous academic field, thus particularly sensitive to pressure and external interference. Relations with other countries, especially in times of war, affected their work and daily lives, on occasion necessitating measures to keep their jobs, carry on research and even avoiding deportation and arrest.

In this article, we argue that Wataghin's assertion of his Russian nationality was a tactic to stay in Brazil and reorganize his work at a time when the country's entry into the Second World War on the side of the Allies made life for Axis nationals living there increasingly difficult.

Wataghin's path will be analyzed according to Pinault's (2003) schema for "intellectual scientists." Based on Sirinelli's (1986) broader concept of intellectuals, the intellectual scientist is a person capable of converting his accumulated scientific knowledge into political capital. This transformation enables the intellectual scientist to engage politically to promote changes in his scientific field. This concept helps guide historical inquiry, as it enables a careful survey of the scientist's itinerary, generational background and social network ${ }^{9}$. In terms of methodology, considering the scientist as an intellectual allows elaborating research questions, mobilize sources, analysis, and writing the historical narrative. It also helps to think about the relationships between the scientist - and science - and his social universe, in the contexts of, among others, war, and technological developments. ${ }^{10}$

The sources consulted are in the Historical Archive of the University of Turin, the Augusto Occhialini Archive (University of Florence, Department of Physics and As-

\footnotetext{
${ }^{4}$ Irene Cardoso, A universidade da comunhão paulista (São Paulo: Autores Associados: Cortez, 1982).

${ }^{5}$ Carlota Boto, "A intelectualidade paulista, o Manifesto dos Pioneiros e a Universidade de São Paulo em sua primeira "missão" (1932-1934)," in História da Educação: global, nacional e regional (Vitória: Edufes, 2019).

${ }^{6}$ Carlos Guilherme Mota, "Ecos da historiografia francesa no Brasil: apontamentos e desapontamentos," in Do positivismo à desconstrução. Idéias francesas na América (São Paulo: Edusp, 2004), 137-158. Patrick Petitjean, "As missões universitárias francesas na criação da USP", in A ciência nas relações BrasilFrança (1850-1950) (São Paulo: Edusp, 1996), 259-330.

${ }^{7}$ Luciana Vieira Souza da Silva, Rogério Monteiro de Siqueira, "An Italian mission at the University of São Paulo: Science and education issues in the diplomatic relationships between Italy and Brazil in the 1930s," Mélanges de l Ecole Française de Rome Italie et Méditerranée 130, no. 2 (2018): 407-419.

${ }^{8}$ André Felipe Cândido da Silva, "A diplomacia das cátedras: a política cultural externa alemã e o ensino superior paulista - os casos da USP e da Escola Paulista de Medicina (1934-1942)," História 32, no. 1 (2013): 401-431; Henrique E. Toma, “Alfred Werner e Heinrich Rheinboldt: genealogia e legado científico," Quím. Nova 37, no. 3 (2014): 574-581.

9 Jean-François Sirinelli, "Os intelectuais," in Por uma história política (Rio de Janeiro: Editora da FGV, 2003), 231-269.

${ }^{10}$ Michel Pinault, "L'intellectuel scientifique: du savant à l'expert," in L'histoire des intellectuels aujourd'hui (Paris: Presses Universitaires de France, 2003), 227-254.
} 
tronomy at Arcetri), the Historical Archive of the Institute of Physics at the University of São Paulo (AHIFUSP), the Archive of the Institute of Brazilian Studies at the University of São Paulo (IEB-USP), the Public Archive of the State of São Paulo (APESP) and Brazilian newspapers from the time (Correio da Manhã and Diário da Noite). The article begins with Wataghin's actions in Brazil, which led him to reconnect with his Russian origins, it then deals with the relationship between Wataghin's engagement in the Russian community and his work as a physicist and university professor, finally, it discusses the investigations of the Brazilian political police into Wataghin's scientific network and the consequences for the USP Physics Department.

\section{Wataghin returns to his Russian roots}

Wataghin introduced himself to the Brazilian university as an Italian, not only because of his citizenship, which he obtained in May $1929,{ }^{11}$ but also for being in the service of the Italian Ministry of Foreign Affairs. ${ }^{12}$ However, Brazilians were not unaware of Wataghin's original nationality. Along with the other members of the FFCL's foreign missions, Wataghin's arrival in São Paulo, with one of the country's largest Community of Italian immigrants, ${ }^{13}$ was covered in the press, which pointed out that the professor was Italian, "despite the fact that his name does not say it." 14 Born in Birsula, Ukraine, Wataghin graduated from the Imperial Gymnasium in Kiev and attended a year at Kiev University between 1918 and 1919. He was a member of a noble and wealthy Russian family, and his father was an engineer. ${ }^{15}$

In the late 1930s, while organizing the documentation for a competition in Italy, Wataghin even declared to his friend and physicist Augusto Occhialini, the father of his colleague Giuseppe Occhialini, that he had been

Baptized into the Orthodox religion, and that I belong to a family of nobles (Russians) and that my parents were also Orthodox. My father, who lived in Turin 10 years, where he was well-known, was an engineer and held important government positions (as director of the southwestern Russian railways). From my grandparents and great-grandparents, I know my origins have been Aryan since 1812. Therefore, I am not a Jew! My wife's Aryan origin is also easy to determine: she is Astigian, born in Mombercelli d'Asti, Catholic like her parents and grandparents. ${ }^{16}$

This was not a frivolous remark. Although the letter is undated, its contents indicate that it was written in $1938 .{ }^{17}$ This was the year Mussolini's anti-Semitic fascist laws were enacted, which stripped Italian Jews of their civil rights, ${ }^{18}$ explaining why Wataghin needed to point out that he was Russian Orthodox, not Jewish.

${ }^{11}$ Enrico Predazzi, "Gleb Wataghin”. In La Facoltà di Scienze Matematiche Fisiche Naturali di Torino. 1848-1998. Tomo Secondo. I Docenti (Torino: Deputazione Subalpina di Storia della Patria/Università degli Studi di Torino, 1999), 283-294.

${ }^{12}$ Historical Archive of the University of Turin. Fascicolo personale Gleb Wataghin.

${ }^{13}$ On the distribution of Italians in the neighborhoods of São Paulo, according to the region of origin, see the works of Ceni (2011) and Carelli (1985).

14 Correio da Manhã, Rio de Janeiro, June 20, 1934, 5.

15 Enrico Predazzi, "Gleb Wataghin," in La Facoltà di Scienze Matematiche Fisiche Naturali di Torino. 1848-1998. Tomo Secondo. I Docenti (Torino: Deputazione Subalpina di Storia della Patria/Università degli Studi di Torino, 1999), 283-294; M.N. Moseykina, "Uchenyy-fizik Gleb Vasil'yevich Vatagin: russkiy emigrant, grazhdanin Italii," in Russkiye v Italii. Ital'yantsy v Rossii. Vzaimovliyaniye kul'tur (St. Petersburg: SpbGASU Publ., 2012), 79-90.

${ }^{16}$ Augusto Occhialini Archive. Letter from Gleb Wataghin to Augusto Occhialini, circa 1938. Doc. 244. Original in Italian.

${ }^{17}$ Wataghin mentioned in the letter a paper he had recently published in Brazil: "Sobre teoria quântica e relatividade," FFCL Physics Bulletin, no. 1 (1938).

${ }^{18}$ Mario Avagliano, Marco Palmieri, Di pura razza italiana. L'Italia “ariana” di fronte alle leggi razziali (Milan: Baldini \& Castoldi, 2013). 
Wataghin immigrated with his family to Italy in 1919 because of the October 1917 Revolution and the Civil War that followed it. ${ }^{19}$ Although there are no documents that explain why Wataghin left Kiev, some hypotheses may be made. In pre- and post-revolutionary Russia, the railroad played a relevant role and helped to industrialize the Empire. In addition to the expansion of the railway network, which grew by 20,000 kilometers between 1860 and 1870 , the liberation of the peasantry from serfdom in 1861 was essential for enabling certain regions of the Empire, such as Ukraine, to industrialize. ${ }^{20}$ During the Civil War, railways were an important strategic asset, as well as the scene of some battles. ${ }^{21}$ As Wataghin told his friend Augusto Occhialini, his father was an engineer responsible for the southwestern railways and it is possible that he faced difficulties as the network was requisitioned during the conflict, not to mention the war's other hardships.

There is no consensus about which path Gleb Wataghin took from Kiev to Turin, in Italy. According to Predazzi (1999), the family fled through Crimea and boarded a ship before the Red Army advanced. They then crossed Greece before landing in Turin. Based on a talk with the writer Primo Levi, the Turin physicist Tullio Regge provides more details. According to Regge, at the time of the Revolution, the Wataghin family was in Kiev and, since two of the four children were officers, all its members were in danger. Therefore,

they got in a train, reached the Black Sea, found an English ship that took them to Greece, where they were about to starve to death. They went on to Belgrade, where their father died. The children went different ways. One of them, who had been a famous lawyer in Russia, went to Rome looking for work, but had a hard time, until one day, Tatiana Pavlova recognized him. She took him to Turin, which was the capital of cinema in the 1920s, to be an administrator of a movie company. This brother called the rest of the family to Turin, but when everyone arrived, the company went bankrupt. Only Gleb remained in Turin. At the age of 18, he was greatly helped by Corrado Segre. ${ }^{22}$

Regge's version bears closer scrutiny. The author himself announces, at the beginning of his passage about Wataghin's life, that the professor's life was "very romantic," which calls into question its accuracy. The most notable inconsistency is the claim that Wataghin's father died during his journey to Turin. However, Wataghin himself recalled in the letter quoted earlier that his father had lived in Turin for ten years, where he was well known. ${ }^{23}$ The most complete version of Wataghin's path to Italy was given by the physicist himself in an interview with the project "History of Science in Brazil," which was coordinated by Simon Schwartzman at Fundação Getúlio Vargas, in the 1970s. According to Wataghin, he and his family went

to Turkey, onto Calipode, Belgrade, and then to Trieste. Then we proceeded to Turin, because it had an important film industry. And it was easy to earn at least what was needed for a family in that sector. I had a father, mother, and a brother to support. I was 19 or 20 years old. So, I joined the cinema. However, despite this, it was at the university... But I did everything: statistics, played the piano, everything. Luckily, I received a good secondary preparation. I even taught Latin, not just math. For my professor - a great friend and great mathematician - I made translations from Russian to Esperanto. I needed to get more work, but it interfered with my studies. Very disruptive. I began doing science very late, as I neared my $30 \mathrm{~s}$, which means I missed the best years. ${ }^{24}$

This brief excerpt reveals several details about Wataghin's early years: He had a good secondary education and spoke several languages. It also sheds light onto his initiation into the labor market and science. Contradicting the other versions of the journey to Italy, Wataghin provides new information, such as the passage through Turkey and Trieste, before reaching Turin.

\footnotetext{
${ }^{19}$ Gleb Wataghin, Gleb Wataghin (depoimento, 1975) (Rio de Janeiro, CPDOC, 2010).

${ }^{20}$ Maurício Tragtenberg, A Revolução Russa (São Paulo: Editora UNESP, 2007).

${ }^{21}$ Jean-Jacques Marie, História da Guerra Civil Russa: 1917-1922 (São Paulo: Contexto, 2017).

22 Primo Levi, Tullio Regge, Dialogo (Milan: Arnoldo Mondadori Editore, 1994), 27-28.

${ }^{23}$ Augusto Occhialini Archive. Letter from Gleb Wataghin to Augusto Occhialini, circa 1938. Doc. 244.

${ }^{24}$ Gleb Wataghin, Gleb Wataghin (depoimento, 1975) (Rio de Janeiro, CPDOC, 2010), 24.
} 
Wataghin played a prominent role in the history of physics in Brazil. ${ }^{25}$ At USP, Wataghin was the only professor in that field until 1937, when it hired his Italian colleague Giuseppe Occhialini. ${ }^{26}$ As in Turin, during his early years in São Paulo, Wataghin continued to devote himself to quantum field theory. In no time, he began conducting experiments in cosmic rays, a topic of great interest among physicists at the time. He focused on so-called showers of particles by explosion resulting from nuclear interaction between cosmic rays and matter. In Brazil, Wataghin and his pupils discovered showers of penetrating particles, the results of which were published in the Physical Review in the 1940s. ${ }^{27}$ Wataghin's versatility, which allowed him to work in both theoretical and experimental physics, played an important role in assembling a diverse group of physicists with various skills. ${ }^{28}$

Wataghin became director of the FFCL-USP Department of Physics, which he had helped to found, and also did much to internationalize it. In addition to attracting important scientists, such as the US physicist Arthur Compton, who came to Brazil in 1941 to participate in the Symposium on Cosmic Rays in Rio de Janeiro and conduct research with Wataghin's group in Sao Paulo, Wataghin also sent his students abroad to work with distinguished names in the field, such as Paulus Aulus Pompeia, who spent some time in Chicago with Compton. ${ }^{29}$

Wataghin's situation at the university changed in 1942, when Brazil entered World War II, having followed the United States in declaring war on Italy and the other Axis countries. All Italian professors at USP were dismissed, except for Wataghin, whose contract for the following year stated his nationality as Russian. ${ }^{30} \mathrm{~A}$ few days after the declaration of war in August 1942, Wataghin had sent a letter to the FFCL director, Fernando de Azevedo, declaring himself to be Russian and therefore tied to the Allied cause. Wataghin pointed out that

\begin{abstract}
despite staying outside my country for 23 years, my dedication and my love for Russia have always dominated my feelings. I have never forgotten that my actions, whether meritorious or flawed, will be judged as those of a Russian, and that the fact that I was naturalized as an Italian in 1930 and entered this country in 1934 with that country's passport, in no way alters this. ${ }^{31}$
\end{abstract}

Although allowed to remain at the university as a professor, Wataghin was removed from the Physics Department's leadership, which was headed by one of his first Brazilian pupils, Marcello Damy de Souza Santos.

${ }^{25}$ Antonio Augusto Passos Videira, Martha-Cecilia Bustamante, "Gleb Wataghin en la Universidad de São Paulo: un momento culminante de la ciencia brasileña," Quipu 10, no. 3 (1993): 263-284; Cássio Leite Vieira, Antonio Augusto Passos Videira, "História e Historiografia da Física no Brasil," Revista de História e Estudos Culturais 4, no. 3 (2007): 1-27; Heráclio Duarte Tavares, Estilo de pensamento em física nuclear e de partículas no Brasil (1934-1975): César Lattes entre raios cósmicos e aceleradores (Rio de Janeiro: Universidade Federal do Rio de Janeiro, 2017).

${ }^{26}$ Leonardo Gariboldi, Giuseppe "Beppo Occhialini. Dal positrone alla mappa gamma della galassia," Emmeci Quadro, agosto (2007): 64-74.

27 Antonio Augusto Passos Videira, Martha-Cecilia Bustamante, "Gleb Wataghin en la Universidad de São Paulo: un momento culminante de la ciencia brasileña," Quipu 10, no. 3 (1993): 263-284.

${ }^{28}$ Cássio Leite Vieira, Antonio Augusto Passos Videira, "História e Historiografia da Física no Brasil," Revista de História e Estudos Culturais 4, no. 3 (2007): 1-27.

${ }^{29}$ Olival Freire Jr., Indianara Silva, "Scientific Exchanges between the United States and Brazil in the Twentieth Century: Cultural Diplomacy and Transnational Movements," in How Knowledge Moves: Writing the Transnational History of Science and Technology (Chicago: The University of Chicago Press: 2019), 281-307.

${ }^{30}$ Luciana Vieira Souza da Silva, Rogério Monteiro de Siqueira, "An Italian mission at the University of São Paulo: Science and education issues in the diplomatic relationships between Italy and Brazil in the 1930s," Mélanges de l Ecole Française de Rome Italie et Méditerranée 130, no. 2 (2018): 407-419.

${ }^{31}$ IEB-USP Archive. Letter from Gleb Wataghin to Fernando de Azevedo, 08/28/1942. Fundo Fernando de Azevedo, FA-CP-Cx34, 13. Original in Portuguese. 
Wataghin's 1943 contract with the FFCL, which stated his nationality as Russian, came precisely during the Estado Novo period, when the situation of the Italians in the country became much more difficult. ${ }^{32}$ Moreover, he recovered his Russian identity not only at the university, but also began to socialize with São Paulo's Russian community by frequenting such organizations as the Brazil - USSR Cultural Union, founded in April 1945, to foster scientific, literary and artistic exchange between the two countries. ${ }^{33}$ Wataghin's most important role, however, was at the Subcomitê Russo de Socorro às Vítimas de Guerra (Russian Subcommittee for the Assistance to War Victims), also known as the Russian Red Cross, as detailed below.

The Brazilian-Russian community began to take shape in the $19^{\text {th }}$ century. Between 1870 and 1953, 118.600 Russian immigrants arrived in Brazil. ${ }^{34}$ In the 1920s, Russian refugees arrived in the country, having left Russia after the 1917 Revolution and the Civil War (1917-1922), a period that coincides with the immigration of the Wataghin family to Italy. Before heading to Brazil, a significant part went to Western Europe, where they sought refuge. ${ }^{35}$

The Russian community of São Paulo city was very heterogeneous. In the first half of the 20th century, it was divided between a social and intellectual elite, who lived in the downtown, and masses of immigrant families, who inhabited the peripheries. The elite was mostly shaped by empire refugees, and the masses of immigrant families came from the empire peripheries to work at the coffee farms. After the coffee crisis, at the end of the 1920s, they moved to São Paulo city. One of the encounter points of both groups were the Orthodox Churches. Although the downtown Russian elite was heterogeneous, it dominated the collective sociability spaces. Between the 1920s and the 1930s, it diffused an anti-communist and anti-Bolshevik discourse, aiming to modify the public opinion about the Russians in Brazil, who were frequently associated with communism. With the entry of Brazil in the Second World War, in August 1942, and the repression of fascism in the country, the conservative Russians lost space for their political manifestation. At the same time, the pro-soviets started to manifest themselves with more freedom. ${ }^{36}$

During the war, new Russian immigrant groups arrived in Brazil. Between the 1940s and the 1950s, their collective institutions were more related to assistentialism, such as the Russian Red Cross. In São Paulo, the idea of being part of the Russian nation was changing following the creation of those entities and the presence of new immigrants. Count Emmanuel Bennigsen, one of the Russian Red Cross founders, and Gleb Wataghin were part of the group of Russians whose "Russianness" went beyond the communismnationalism dichotomy. According to the documents of the period, they believed that the Soviet regime would be transitory, and they supported the Allies in the war against Nazism. ${ }^{37}$ However, as we will see below, the entity and its members were accused of the crime of communism, which provoked important reconfigurations in Wataghin's itinerary and daily work, as well as in his network of sociability.

Brazil maintained diplomatic relations with the Soviet Union for the short period of 1945 and 1947, due to pressure from its wartime ally, the United States, which itself had

32 During the dictatorship of the Estado Novo, laws were enacted that prohibited the citizens of the Axis from expressing themselves politically and even speaking their native languages publicly (Santos 2008).

${ }_{33}$ Diário da Noite, Rio de Janeiro, 04/25/1945, 3.

${ }^{34}$ Anastassia Bytsenko, Imigração da Rússia para o Brasil no início do século XX. Visões do Paraíso e do Inferno (São Paulo: University of São Paulo, 2006).

35 Svetlana Ruseishvili, Ser russo em São Paulo: os imigrantes russos e a (re)formulação de identidade após a Revolução Bolchevique de 1917 (São Paulo: University of São Paulo, 2016).

36 Ibid.

${ }^{37}$ Ibid. 
only a few years earlier recognized the country. ${ }^{38}$ Brazil's entry into the war led to the creation of charitable organizations, such as the Russian Red Cross, which was founded in September 1943. ${ }^{39}$ According to the entity's bylaws, men and women could join as members as long as they were not engaged in illegal activities, those "against honor and dignity," or if they had been convicted of crimes against national security. ${ }^{40}$

Despite having been authorized by the Brazilian government, the Russian Red Cross was under the surveillance of the political police of the State Department of Political and Social Order of São Paulo (DEOPS/SP). ${ }^{41}$ Its investigators went to balls, charity teas and other cultural events, sending detailed reports to the Political Order Policing Section. ${ }^{42}$ Although there were decrees prohibiting immigrants from speaking in foreign languages, many activities were carried out in Russian or other languages than Portuguese, which was always noted by DEOPS agents. ${ }^{43}$ Wataghin joined the Russian Red Cross in 1944, rising to vice-president, ${ }^{44}$ which earned him the label of communist with DEOPS. ${ }^{45}$ He left the position in September 1947, to focus on travel and scientific research. ${ }^{46}$

The end of the Estado Novo coincided with the end of World War II, in 1945. Even so, the Getúlio Vargas regime's authoritarian practices continued in Brazil, including the repression of immigrants. Nevertheless, during the war communists had celebrated the Soviet Union's victories against the Nazis by waving red flags in their social organizations. Anti-communists, in turn, followed the victories of the Red Army with dismay, and after Brazil's entry into the war with the Allies, Nazi and other fascist activities began to be forbidden. ${ }^{47}$ However, this did not diminish the fear of communism among certain Brazilian authorities, which was rooted in popular and police imagery. ${ }^{48}$ Their anticommunism led them to report the members of the Russian Red Cross to DEOPS. As a result, the police concluded that it was affiliated with the party, ${ }^{49}$ although many of its members, such as Wataghin, had no political affiliation.

It is not known whether Wataghin knew that the Russian community was being followed by DEOPS, or that he was classified as a communist. Even so, one has to wonder what led him to approach this group. According to a DEOPS report of March 1945 Wataghin,

was persecuted, spent two years on reduced pay, which forced him to embrace "Soviet patriotism." A prominent physicist, he intended to return to the "Soviets," where people of this class were said to enjoy certain perks. "He is protected by the global leader in physics (ellipsis), who, working in England,

${ }^{38}$ Rodrigo Pato Sá Motta, "O Perigo é Vermelho e vem de Fora: O Brasil e a URSS," Locus: Revista de História 13, no. 2 (2007): 227-246.

${ }^{39}$ Erick Reis Godliauskas Zen, Imigração e Revolução: Lituanos, Poloneses e Russos sob Vigilância do Deops (São Paulo: Editora da Universidade de São Paulo, FAPESP, 2010). APESP/DEOPS. Bylaws of the Russian Subcommittee for the Assistance to War Victims (authorized by the Red Cross), p. 1. Record 1325.

40 APESP/DEOPS. Bylaws of the Russian Subcommittee for the Assistance to War Victims (authorized by the Red Cross), p. 2. Record 1325. Original in Portuguese.

${ }^{41}$ Erick Reis Godliauskas Zen, Imigração e Revolução: Lituanos, Poloneses e Russos sob Vigilância do Deops (São Paulo: Editora da Universidade de São Paulo, FAPESP, 2010).

42 APESP/DEOPS. Report of the researchers Benevenuto Boschetti and Pedro Assaf, 12/16/1946. Record 1325.

${ }^{43}$ Erick Reis Godliauskas Zen, Imigração e Revolução: Lituanos, Poloneses e Russos sob Vigilância do Deops (São Paulo: Editora da Universidade de São Paulo, FAPESP, 2010).

${ }^{44}$ APESP/DEOPS. Secret Service Circular Letter of 06/14/1965. Record 50-Z-030.

45 Ibid.

46 AHIFUSP. Letter from Gleb Wataghin to Pedro Ayres, Chairman of the Red Cross, 08/29/1947. Doc. 2,198 , cx. 2 , p. 7 .

${ }^{47}$ Erick Reis Godliauskas Zen, Imigração e Revolução: Lituanos, Poloneses e Russos sob Vigilância do Deops (São Paulo: Editora da Universidade de São Paulo, FAPESP, 2010).

${ }^{48}$ Rodrigo Pato Sá Motta, "O Perigo é Vermelho e vem de Fora: O Brasil e a URSS," Locus: Revista de História 13, no. 2 (2007): 227-246.

${ }^{49}$ Erick Reis Godliauskas Zen, Imigração e Revolução: Lituanos, Poloneses e Russos sob Vigilância do Deops (São Paulo: Editora da Universidade de São Paulo, FAPESP, 2010). 
imprudently left his wife and son behind in the Soviet Union as hostages, and was forcibly returned to his homeland." The topic is as follows: (We will note that the world famous Doctor of Chemistry, General Ipatiouv stayed in the USA) and adds: 'Here is the explanation of G. Wataghin's sudden collaboration with the "Jews of the Red Cross" and Count E. Benningsen' [the entity's chairman]..$^{50}$

While much of this report was inaccurate, it may explain why Wataghin left Brazil and returned to Italy a few years later. According to the aforementioned passage, for example, the physicist received reduced pay for two years, but it provided no further details, such as the amount by which it was reduced.

DEOPS also tracked Wataghin's movements outside the Russian Red Cross, especially his international travel and the relations he established abroad. In 1945, USP itself informed DEOPS that Wataghin would make a trip to Argentina to check for any problems, "since he will be a representative of this educational institution." It is not known why the university sought out the political police, but it may have had suspicions about the professor's involvement in subversive activities, since the same document mentioned his work with the board of the Russian Red Cross, and was included in an extensive report on communists linked to the university. ${ }^{51}$

\section{Wataghin's scientific network under investigation in Brazil}

\section{A confidential report of January 1946 states that}

Mrs. Estrela Mazzoli de Mathov (Buenos Aires), Mario Mathov's sister-in-law, editor of the Sovietbased magazine Seleciones soviéticas, published in Buenos Aires, received a scholarship from the Faculty of Philosophy at USP under the influence of the reds. ${ }^{52}$

Thus, DEOPS considered it noteworthy that Wataghin went to Argentina, where, despite representing USP, he met with alleged communists and, moreover, arranged scholarships in the FFCL Physics Department. DEOPS reports point out that these physicists came to Brazil in 1946, but the date of the correspondence between Wataghin and Teófilo Isnardi of the University of Buenos Aires, Professor of Estrella Mazzoli de Mathov, Waldemar Jorge Kowalewsky and Dóra Genijóvich Kowalewsky, is February 1947. Moreover, contrary to the DEOPS' reports, the students had no scholarship when they arrived, which, incidentally, was a concern for Wataghin. ${ }^{53}$ Isnardi, who wanted his students to work effectively with cosmic rays, sought funds for the students' stay in Brazil. ${ }^{54}$ He was also worried that the Physics Department was not autonomous, but subject to faculty and university decisions. ${ }^{55}$

At the FFCL, Waldemar Jorge Kowalewsky and Dora Genijóvich Kowalewsky, along with other physicists, presented lectures to the Physics Seminar. This seminar has been a student activity of the Department of Physics and Mathematics since 1935, when Wataghin and the mathematician Luigi Fantappiè organized it (It was subsequently divided into two separate seminars for mathematics and physics). During their meetings, students were encouraged to present their research, as well participate in discussions about the research of their professors and guest professors. ${ }^{56}$ During her exchange at the FFCL,

${ }^{50}$ APESP/DEOPS. Secret Service Circular Letter of 06/14/1965. Record 50-Z-030. Brackets added. Original in Portuguese.

${ }^{51}$ APESP/DEOPS. Report of the Specialized Police Department of Social Order. Record 50-K-104, doc. 731. Original in Portuguese.

52 APESP/DEOPS. Secret Service Circular Letter of 06/14/1965. Record 50-Z-030. Brackets added. Original in Portuguese.

${ }^{53}$ AHIFUSP. Letter from Gleb Wataghin to Isnardi, 02/09/1947. Doc. 2,148, cx. 2, p. 7.

${ }^{54}$ AHIFUSP. Letter from Teófilo Isnardi to Gleb Wataghin, 02/20/1947. Doc. 2,151, cx. 2, p. 7.

55 Ibid.

${ }^{56}$ Luciana Vieira Souza da Silva, Rogério Monteiro de Siqueira, "An Italian mission at the University of São Paulo: Science and education issues in the diplomatic relationships between Italy and Brazil in the 1930s," Mélanges de l Ecole Française de Rome Italie et Méditerranée 130, no. 2 (2018): 407-419. 
Dora Kowalewsky talked about "Spectrons rotacionaes e vibracionaes de moleculas díatomicas," while Waldemar Kowalewsky presented the paper "Teoria da descarga dos contadores Geiger Müller." ${ }^{, 7}$ Dora also participated in the Physics Colloquium, with a report on the debate "Conceitos fundamentais sobre os espectros de vibração e rotação," as did Estrella de Mathov, with a paper on "Meson disintegration." 58

While in Brazil, these young people were investigated by DEOPS agents, who sought information even from the FFCL, ${ }^{59}$ and followed the students' footsteps since their arrival. An agent specific for the case, a.k.a. R.C., was designated to be in charge of "clarifying Mrs. Estrela Mazzoli de Mathov's connections in this Capital," and presented a report on her activities in Rio de Janeiro. ${ }^{60}$ Waldemar and Dora Kowaleski were also closely observed during their stay in Rio de Janeiro, as part of investigations linked to the fight against communism. ${ }^{61}$ Waldemar was quoted as the chief of the Polish Communists of Buenos Aires, and the students were qualified as part of the "red agitators who have special missions in our country.",62

It did not take an affiliation with the Communist Party to be classified by DEOPS as a Communist; simple friendships or even professional relationships were enough to become a target of its investigations. The FFCL Physics Department's work, as well as its scientists and visitors, were closely monitored by law enforcement officials, especially due to the presence of Wataghin, who was classified as communist. The scientific field that was under formation with the FFCL Physics Department, if seen through Wataghin's social movements, was structured in power relations not only according to scientific, cultural, political and diplomatic interests, but also to those of the police.

This "witch hunt" of communists at USP would not have been as effective without help from inside the university. Sometimes undercover agents were discovered among the students, which led them to advise the FFCL board to have "an element of total confidence by being on guard," by taking care of the building whose laboratories and valuable materials could be damaged. According to information FFCL's director, Astrogildo Rodrigues de Mello, gave to the Secret Service, that faculty had "various communist elements, not only among professors, but also among students," especially in physics, such as the students Enio Sandoval Peixoto, Paulo Saraiva de Toledo, Roberto Aureliano Salmeron and Paulo Sergio de Magalhães Macedo. To the Deputy Delegate of the Police Department of Political and Social Order (DOPS), Paulo Rangel,

to control effectively the harmful activities of some members of the Faculty of Philosophy, Sciences and Languages, both among professors and students, the competent D.O.P.S. service should organize permanent surveillance and infiltration, not only to confirm the detail pointed out by the Board of Directors, but also safely control the activities of the elements concerned. ${ }^{63}$

During the Cold War, special attention was also paid to research in the Department of Physics, especially that involving nuclear physics. In 1948, DEOPS produced a detailed report on each student and professor associated with the Department and their research. The document highlights the first experiments on cosmic rays carried out by physicists in Brazil, which would have placed São Paulo at the

${ }_{57}$ AHIFUSP. Schedule of the Physics Seminar, of 03/13/1947. Doc. 2.1.5, cx. 3, p. 11.

${ }^{58}$ AHIFUSP. Schedule of the Colloquium of Physics, from 03/03/1947 and 03/10/1947. Doc. 2.1.7, cx. 3, p. 11 .

${ }^{59}$ APESP/DEOPS. Preliminary Information, of 01/04/1947. Dossier 30-Z-0-773.

${ }^{60}$ APESP/DEOPS. Topic of a reserved report from Rio, of 01/02/1947. Dossier 30-ZO-773. Original in Portuguese.

61 APESP/DEOPS. Report prepared by the O.E. Sector, 01/10/1947. Dossier 30-Z-0-773.

62 APESP/DEOPS. [Untitled document], s./d. Dossier 30-Z-0-773. Original in Portuguese.

${ }^{63}$ APESP/DEOPS. Report of the Deputy Delegate of the Political Order Paulo Rangel, of 09/29/1949. Dossier 50-H-32-25. Original in Portuguese. 
forefront of South and Central America, still possessing little human and mechanical material, but much more than any other country. Less, of course, than the United States. ${ }^{64}$

Even Gleb Wataghin's first theoretical work, which involved the study of relativistic electrodynamics and theory of electron equilibrium, positron and nuclei at elevated temperatures, were mentioned.

The report's political character, aside from DEOPS's concern with nuclear-related research, is apparent from comments about the ideology of each of the Department's members. With regard to Wataghin, it stated that he was the

oldest contributor to the Department of Physics [...] [He is] Russian by birth [and] a naturalized Italian. In July 1947, with the resignation of Count Emanuel Benningsen, he took over the board of the Subcomitê Russo de Socorro às Vítimas de Guerra in S. Paulo (This subcommittee was a communist center). ${ }^{65}$

It is noteworthy that Wataghin ceased to belong to the subcommittee in August 1947, according to a letter sent to Pedro Ayres, quoted above.

The report levelled one criticism in particular at Wataghin: the "learned man has ninety-six (96) published papers. Not one of them is in Portuguese." ${ }^{\prime 66}$ For the police, this indicated that the Russian physicist was not engaged with Brazil's national cause. In fact, this was not true, since Wataghin had already published several works in Portuguese in the Annals of the Brazilian Academy of Sciences and in the FFCL Physics Bulletin.

Wataghin's involvement in the red cause was more than evident to the police, and Estrella de Mathov's arrival in Brazil left no doubt as to his real intentions. According to the report, the young physicist was Mario Mathov's sister-in-law,

editor of the Russian propaganda magazine Selecciones Sovieticas, published in Buenos Aires, took a scholarship from the Faculty of Philosophy of the University of São Paulo, influenced by Mario Schenberg, whose political ideology has already been described above, then went to Argentina, visited the University of Cordoba, and there invited Professor Guido Beck to come to Brazil. Upon acceptance of the invitation, that learned man was in our Nuclear Physics laboratories three or four times, saw, studied and researched what he understood... ${ }^{67}$

At this point in the report, DEOPS expressed its concerns about the presence of communist elements at USP, and that their dangerous knowledge of nuclear physics might enable them to build an atomic bomb. ${ }^{6}$

The police also recognized that Brazil had "need of these and other learned people, but it is also true that we should exercise greater, more efficient supervision, restricting to the national scope to what is most important for our defense." 69 In DEOPS's opinion, it was necessary to set limits on scientific work at FFCL. The police's strategy was linked to the broader one of promoting Brazilian nationalism. After all,

as it turns out, it was urgent to give the national field the place it needs to have: To be the first in everything. Within the dear and sacred image of the Homeland, let us forget hatred, anger, preference, partisan passion, political revenge. Let us put the National Cause above all causes, Brazil's interest above all interests. ${ }^{70}$

The police's concerns were that Wataghin and his pupils' knowledge of nuclear physics could make constructing an atomic bomb feasible. Coupled with the presence of communist elements in their social network, this would be sufficient for them to be con-

${ }^{64}$ APESP/DEOPS. Report on nuclear physics research at the Department of Physics, Faculty of Philosophy, Sciences and Languages, Universidade de São Paulo, 1948. Dossier 50-H-32-24 “b”, p. 1. Original in Portuguese.

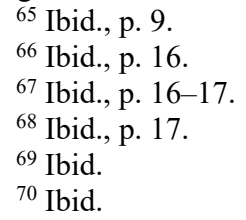


sidered as threats to national security. To DEOPS, the national origin of the communists was less important than their Judaism. As they saw it, all

propaganda and disturbances come from the Jews (so-called North American, French, German, Russians, Argentines, etc.). Revolutions, freedom, progress - these all help Judaism, in Israel's march to world domination! ${ }^{71}$

Wataghin was not Jewish, but to the political police he was a still militant of the so-called International Judaism, ${ }^{72}$ which suggests considerable ignorance and prejudice among its agents.

Although Wataghin's scientific work was relevant, as well as critical for the development of physics in São Paulo, the police could not tolerate supporters of the "red belief" at the university. Those suspected of conspiring against national security had to be closely monitored. ${ }^{73}$ One result was that almost all Russian émigrés in Sao Paulo were targeted by DEOPS as undercover agents of the communist cause. ${ }^{74}$ Given the great political hostility to this community, one might wonder whether the pursuit of communists at the university itself was directly related to Wataghin's return to Italy in 1949.

According to a report by Jacow Sacharowitsch Suriz, who arrived in Brazil as the Soviet ambassador in 1945, among the émigrés who applied for Soviet citizenship was a request from Wataghin, which received no reply. After the closure of the Russian Red Cross and the new diplomatic rupture between Brazil and the Soviet Union in 1947, Wataghin may have received a friendly suggestion that he leave Brazil, but this only happened in $1949 .{ }^{75}$

\section{Conclusion}

Wataghin never spoke publicly about his political beliefs. In an interview, Wataghin commented that

I, who considered myself socialist, was personally very much in favor of the Revolution. In a way, some of the violence disturbed me. Violence is not necessary, because great part of the population supports the revolution. Nevertheless, it is very difficult to judge and evaluate the movements of great masses. Of course. ${ }^{76}$

The police concluded that Wataghin was communist for taking part in an entity that supported the USSR in the war against Hitler, although neither the Russian Red Cross nor Wataghin was communists. Despite the police complaints, this research did not found a single declaration of Wataghin, from the 1940s, that could corroborate the authorities' suspicions. Even before his participation in this entity, Wataghin had declared disposition to support the Allies in the Second World War. When he evoked his "Russianness," the physicist joined the group of Russians in Brazil for whom "being Russian" meant to support the Soviet Union in the war against nazi-fascism - confirming what Ruseishvili (2016) discusses in her thesis.

His behavior in the face of Fascist Italy's foreign policy, which brought him to Brazil, as well as the accusations and investigations to which he was subjected as a Russian,

${ }^{71}$ APESP/DEOPS. Corrections to reports made, s./d. Dossier 30-J-3-46, p. 3. Original in Portuguese.

72 Zen (2010) notes that the police's documents from the period show that, in the mid-1940s, the mythology that Jews conspired to take over the world had very much returned. According to the author, "although some documents manifest themselves as delusions of the disturbed mind of an anti-Semitic fanatic, what should be considered is the recurrence of this discourse" (Zen 2010, 163, original in Portuguese).

${ }^{73}$ In addition to Gleb Wataghin, another recurring name in DEOPS reports is that of one of his pupils and future FFCL professor, the theoretical physicist Mario Schenberg, a member of the Brazilian Communist Party.

${ }^{74}$ Erick Reis Godliauskas Zen, Imigração e Revolução: Lituanos, Poloneses e Russos sob Vigilância do Deops (São Paulo: Editora da Universidade de São Paulo, FAPESP, 2010).

75 M.N. Moseykina, "Father of Brazilian Nuclear Physics. Gleb Vasilievich Vatagin in Sao Paulo," Rodina, no. 10 (2013): 62-64.

${ }^{76}$ Wataghin, Gleb. Gleb Wataghin (depoimento, 1975). Rio de Janeiro, CPDOC, 2010. P. 5. 
must be analyzed with the care that any historical inquiry requires. Events must be put in their proper time. The accusations of DEOPS were unfounded since they were mainly based on the authorities' fear of a supposed communist conspiracy in Brazil. As a physicist and vice-president of an organization considered to be communist, Wataghin was automatically suspect.

Throughout his life, Wataghin tried to adapt to changes in national and international politics, beginning with his departure from Russia during the Civil War to his return to Italy some 30 years later. Wataghin continued to work with cosmic rays and maintain his social network, adapting to the opportunities and obstacles in his way. Despite the controversies regarding his ideological beliefs, we agree with Lesley Chamberlain (2008), who, in her book about intellectuals expelled from the Soviet Union in 1922, argues that it is necessary to consider the trajectories of intellectuals in light of how politics affected their daily lives. In his Brazilian years and even in later on, Wataghin was attentive to the cultural diplomacy relations and did his best to promote them as a scientist and university professor. By the same token, during his varied journey as an exile, he succeeded in setting his own path, according to the scientific, social, political, cultural, and diplomatic changes.

Рукопись поступила: 22 января 2020 г.

Submitted: 22 January 2020.

\section{References}

Avagliano, Mario, and Palmieri, Marco. Di pura razza italiana. L'Italia "ariana" di fronte alle leggi razziali. Milan: Baldini \& Castoldi, 2013 (in Italian).

Bontempi Jr., Bruno. "Nacionalismo e regionalismo em dois inquéritos sobre o ensino superior brasileiro nos anos 1920." Educar em Revista 33, no. 65 (2017): 35-50 (in Portuguese).

Boto, Carlota. "A intelectualidade paulista, o Manifesto dos Pioneiros e a Universidade de São Paulo em sua primeira "missão" (1932-1934)". In História da Educação: global, nacional e regional, 39-74. Vitória: Edufes, 2019 (in Portuguese).

Bytsenko, Anastassia. Imigração da Rússia para o Brasil no início do século XX. Visões do Paraíso e do Inferno. São Paulo: University of São Paulo, 2006 (in Portuguese).

Cardoso, Irene. A universidade da comunhão paulista. São Paulo: Autores Associados: Cortez, 1982 (in Portuguese).

Carelli, Mario. Carcamanos e comendadores: os italianos de São Paulo: da realidade à ficção (1919-1985). São Paulo: Ática, 1985 (in Portuguese).

Ceni, Franco. Italianos no Brasil. São Paulo: EDUSP, 2011 (in Portuguese).

Chamberlain, Lesley. A guerra particular de Lenin. Rio de Janeiro: Record, 2008 (in Portuguese).

Freire Jr., Olival, and Silva, Indianara. "Scientific Exchanges between the United States and Brazil in the Twentieth Century: Cultural Diplomacy and Transnational Movements". In How Knowledge Moves: Writing the Transnational History of Science and Technology, 281-307. Chicago: The University of Chicago Press, 2019.

Garcia, Sylvia Gemignani. Destino impar. Sobre a formação de Florestan Fernandes. São Paulo: Editora 34, 2002 (in Portuguese).

Gariboldi, Leonardo. "Giuseppe "Beppo Occhialini. Dal positrone alla mappa gamma della galassia." Emmeci Quadro, agosto (2007): 64-74 (in Italian).

Levi, Primo, and Regge, Tullio. Dialogo. Milan: Arnoldo Mondadori Editore, 1994 (in Italian).

Marie, Jean-Jacques. História da Guerra Civil Russa: 1917-1922. São Paulo: Contexto, 2017 (in Portuguese).

Moseykina, M.N. Uchenyy-fizik Gleb Vasil'yevich Vatagin: russkiy emigrant, grazhdanin Italii. In Russkiye v Italii. Ital'yantsy v Rossii. Vzaimovliyaniye kul'tur, 79-90. St. Petersburg: SpbGASU Publ., 2012 (in Russian).

Moseykina, M.N. "Father of Brazilian Nuclear Physics. Gleb Vasilievich Vatagin in Sao Paulo." Rodi$n a$, no. 10 (2013): 62-64 (in Russian).

Mota, Carlos Guilherme. "Ecos da historiografia francesa no Brasil: apontamentos e desapontamentos". In Do positivismo à desconstrução. Idéias francesas na América, 137-158. São Paulo: Edusp, 2004 (in Portuguese). 
Motta, Rodrigo Pato Sá "O Perigo é Vermelho e vem de Fora: O Brasil e a URSS." Locus: Revista de História 13, no. 2 (2007): 227-246 (in Portuguese).

Petitjean, Patrick. As missões universitárias francesas na criação da USP. In A ciência nas relações Brasil-França (1850-1950), 259-330. São Paulo: Edusp, 1996 (in Portuguese).

Pinault, Michel. "L'intellectuel scientifique: du savant à l'expert." In L'histoire des intellectuels aujourd'hui, 227-254.Paris: Presses Universitaires de France, 2003 (in French).

Predazzi, Enrico. "Gleb Wataghin". In La Facoltà di Scienze Matematiche Fisiche Naturali di Torino. 1848-1998. Tomo Secondo. I Docenti, 283-294. Torino: Deputazione Subalpina di Storia della Patria/Università degli Studi di Torino, 1999 (in Italian).

Ruseishvili, Svetlana. Ser russo em São Paulo: os imigrantes russos e a (re)formulação de identidade após a Revolução Bolchevique de 1917. São Paulo: University of São Paulo, 2016 (in Portuguese).

Santos, Viviane Teresinha dos. Italianos sob a mira da polícia política: vigilância e repressão no estado de São Paulo (1924-1945). São Paulo: Humanitas, 2008 (in Portuguese).

Silva, André Felipe Cândido da. "A diplomacia das cátedras: a política cultural externa alemã e o ensino superior paulista - os casos da USP e da Escola Paulista de Medicina (1934-1942)." História 32, no. 1 (2013): 401-431 (in Portuguese).

Silva, Luciana Vieira Souza da, and Monteiro, Rogério. "Luigi Fantappiè: mathematical analysis, education, and fascism in Brazil (1934-1939)." Lett. Mat. Int.Ed., no. 6 (2018): 153-159.

Silva, Luciana Vieira Souza da, and Siqueira, Rogério Monteiro de. "An Italian mission at the University of São Paulo: Science and education issues in the diplomatic relationships between Italy and Brazil in the 1930s." Mélanges de l Ecole Française de Rome Italie et Méditerranée 130, no. 2 (2018): 407-419.

Sirinelli, Jean-François. "Le hasard ou la nécessité, une histoire en chantier: l'histoire des intellectuels." Vingtième Siècle, revue d'histoire, no. 9 (1986): 97-108 (in French).

Sirinelli, Jean-François. "Os intelectuais." In Por uma história política, 231-269. Rio de Janeiro: Editora da FGV, 2003 (in Portuguese).

Tavares, Heráclio Duarte. "Estilo de pensamento em física nuclear e de partículas no Brasil (1934-1975): César Lattes entre raios cósmicos e aceleradores.” Rio de Janeiro: Universidade Federal do Rio de Janeiro, 2017 (in Portuguese).

Tragtenberg, Maurício. A Revolução Russa. São Paulo: Editora UNESP, 2007 (in Portuguese).

Toma, Henrique E. “Alfred Werner e Heinrich Rheinboldt: genealogia e legado científico.” Quím. Nova 37, no. 3 (2014): 574-581 (in Portuguese).

Videira, Antonio Augusto Passos, and Bustamante, Martha-Cecilia. "Gleb Wataghin en la Universidad de São Paulo: un momento culminante de la ciencia brasileña.” Quipu 10, no. 3 (1993): 263-284 (in Spanish).

Vieira, Cássio Leite, and Videira, Antonio Augusto Passos. "História e Historiografia da Física no Brasil." Revista de História e Estudos Culturais 4, no. 3 (2007): 1-27 (in Portuguese).

Wataghin, Gleb. Gleb Wataghin (depoimento, 1975). Rio de Janeiro: CPDOC, 2010 (in Portuguese).

Zen, Erick Reis Godliauskas. Imigração e Revolução: Lituanos, Poloneses e Russos sob Vigilância do Deops. São Paulo: Editora da Universidade de São Paulo, FAPESP, 2010 (in Portuguese).

\section{Информация об авторах / Information about the authors}

Лучиана Виейра Соуза да Силва, кандидат наук по истории образования и историографии, Университет Сан-Паулу (Бразилия).

Бруно Бонтемпи мл., доцент педагогического факультета Университета Сан-Паулу (Бразилия).
Luciana Vieira Souza da Silva, PhD in History of Education and Historiography, University of São Paulo (Brazil).

Bruno Bontempi Jr., Associate Professor, Faculty of Education, University of São Paulo (Brazil). 